\title{
Mineralogická charakteristika sekundárních změn miocenních vulkanoklastických hornin z jižní a stř̌ední Moravy (Česká republika)
}

\author{
Mineralogical characteristic of secondary alteration of Miocene volcaniclastic rocks \\ in South and Middle Moravia (Czech Republic)
}

\section{David Buriánek $\leftrightarrows$, Oldřich Krejčí, Vladimíra Krejčí, Pavla Tomanová Petrová}

Česká geologická služba, Leitnerova 22, 60200 Brno, Česká republika

\begin{abstract}
Key words:
Carpathian Foredeep, Lower and Middle Miocene, volcaniclastic rocks, bentonite deposit, secondary alteration, smectite
\end{abstract}

$\square$ david.burianek@geology.cz

Editor:

Zdeněk Losos

\begin{abstract}
Bentonite is a significant industrial raw material which deposits deserve protection. The initiative for elaborating this study was the decision from November 2019 of the current owner (the town of Ivančice) to remediate the entire area of the deposit Ivančice-Réna. Lower Miocene volcaniclastic rocks from the Ivančice-Réna (Ivančice) and Middle Miocene sediments in surrounding area of Lipník nad Bečvou are relatively rich in clay minerals (smectites). The mineralogical characteristics of the volcaniclastic rocks were examined using several methods: polarized-light microscopy, X-ray powder diffractometry (XRD), electron microprobe (SEM-WDX), and whole-rocks chemical analysis (ICP-MS). Acid ash-fall tuff and/or very fine-grained tuffite form layers with variable thickness (several $\mathrm{cm}$ to $\mathrm{m}$ ). Grains larger than clay fraction are formed by K-feldspars, plagioclase, biotite, muscovite and quartz crystals accompanied by fragments of pumice and glass shards. The whole-rocks chemical composition of the investigated volcaniclastic rocks indicates similar magmatic sources for both examined samples ( $Y=28$ and $29 \mathrm{ppm}, Y b=2.8$ and $3.2 \mathrm{ppm}$, $\mathrm{Nb}=12$ and $14 \mathrm{ppm}, \mathrm{Ta}=1.1$ and $1.2 \mathrm{ppm}, \mathrm{Zr} / \mathrm{Ti}=0.16$ and 0.17 and $\mathrm{Nb} / \mathrm{Y}=0.4$ and 0.5 ). The formation of smectite from alteration of rhyolite volcanic glass is accompanied by an increased loss on ignition (LOI: 9.4 and $20.2 \mathrm{wt}$. \%) together with a decrease in $\mathrm{K}_{2} \mathrm{O}(0.7$ and $2.1 \mathrm{wt} . \%)$ and $\mathrm{Na}_{2} \mathrm{O}$ (0.6 and $2.1 \mathrm{wt}$. \%). The absence of a negative Ce anomaly suggests that secondary alterations took place under suboxic or anoxic conditions. Smectite and minor opal partially replace volcanic glass and pumice shards. Plagioclase $\left(A b_{59-60}\right)$ and $\mathrm{K}$-feldspar ( $\left.\mathrm{Or}{ }_{62-78} A b_{21-33} A n_{0-1}\right)$ crystals are relatively fresh (weak sericitic alteration). Biotite is partly to wholly oxidized and chloritized (4.9-6.2 wt. \% $\mathrm{K}_{2} \mathrm{O}$ ). Iron oxyhydroxides are present only as minor components. Variation of intensity of secondary alteration (bentonitization) within the studied volcanoclastic layer from the Ivančice-Réna suggests sedimentation in lacustrine environment. In contrast to the case of the sample from Lipnik nad Bečvou, the smectite was formed authigenetically from volcanic glass in interaction with seawater or during an early diagenetic process.
\end{abstract}

\section{Úvod}

Polohy tufů, případně tefry, představují ideální nástroj pro korelaci sedimentárních formací v mořském i kontinentálním prostředí. Během velkých erupcí (především pliniovského typu) totiž pokryje pyroklastický materiál s poměrně homogenním petrografickým a chemickým složením rozsáhlé území. Avšak depozičními a post-depozičními procesy se mohou minerální a chemické složení těchto uloženin měnit. Vulkanické sklo je termodynamicky nestabilní a rozpadá se snadněji než minerální fáze, které jsou ve vulkanoklastických horninách obsaženy (živce, slídy). Hydratace a následná rekrystalizace 
vedou k redistribuci některých chemických prvků mezi vulkanickým sklem a vodnými roztoky v jeho okolí. Vulkanické sklo je tak postupně nahrazováno sekundárními minerály. Tímto způsobem vznikají i bentonity, které jsou dnes velmi žádaným materiálem mimo jiné díky svým sorpčním vlastnostem. Sklem bohaté pyroklastické a vulkanoklastické horniny představují ideální materiál pro studium nízkoteplotních změn vulkanického skla (zvětrávání, diageneze, hydrotermální alterace).

Charakter sekundárních přeměn vulkanického skla není doposud detailně pochopen (Iijima 1978; Izett et al. 1970; Fisher a Schmincke 1984; Preece et al. 1992). Jedná se zejména o vznik bentonitu $\mathrm{z}$ kyselých vulkanoklastik (Ddani et al. 2005; Christidis a Huff 2009). Je to dáno vysokým poměrem $\mathrm{Si} / \mathrm{Al}$, který při sekundárních přeměnách upřednostňuje vznik minerálů ze skupiny $\mathrm{SiO}_{2}$ (křemene, opálu, chalcedonu) a alkalických zeolitů (např̀. heulandit). Naším cílem je přispět k pochopení rozpadu ryolitového vulkanického skla a lépe charakterizovat směs minerálů, které tímto způsobem vznikají. Mineralogické a chemické studium dvou odlišných lokalit vulkanoklastik nám umožnilo detailně popsat rozpad vulkanického skla. První lokalita se nachází na lokalitě Réna v Ivančicích jz. od Brna (Nehyba a Roetzel 1999) a druhá na v. okraji Lipníka nad Bečvou (Bubík et al. 2018a, b; Bubík et al. 2019).

\section{Výskyt vulkanoklastických miocenních hornin na jižní a střrední Moravě}

Spodnomiocenní (svrchní eggenburg-karpat) lokality na jihozápadní Moravě byly poměrně detailně studovány včetně geochronologie např́klad Nehybou (1997) a Nehybou a Roetzelem (1999), naproti tomu vulkanoklastika spodnobadenského stáŕí jsou sice známa dlouhodobě (Slavík 1956; Jurková a Tomšík 1959; Krystek 1959), ale jejich detailní geochemická charakteristika chybí (viz Peloušek a Sirný 1998).

Výskyt pyroklastického materiálu v sedimentech spodního miocénu (svrchní eggenburg-karpat) byl popsán $\mathrm{z}$ řady míst, jak z povrchových výchozů, tak z vrtů na jižní Moravě a v Dolním Rakousku (Čtyroký 1982, 1991; Čížek et al. 1990; Nehyba a Roetzel 1999; Roetzel et al. 2014; Nehyba a Stráník 2016). Z petrografického hlediska můžeme tyto horniny klasifikovat jako tufy, tufity, bentonity a smektitové jíly (Nehyba 1997; Nehyba a Roetzel 1999). Chemické složení primárních vulkanických hornin odpovídalo vápenato-alkalickým dacitům nebo ryolitům (Nehyba 1997; Nehyba a Roetzel 1999). Zirkon ze spodnomiocenních lokalit na Moravě byl datován metodou fission-track, přičemž bylo zjištěno stáří 20,3 \pm 2,4 Ma (Nehyba 1997; Nehyba a Roetzel 1999). Podle Nehyby a Roetzela (1999) je toto stáří svázáno s horizontem vulkanoklastik, které pocházejí z vulkanických center na Slovensku nebo v Mad’arsku. Na jižní Moravě (okolí Miroslavi) a v Rakousku byly zjištěny také mladší horizonty ottnangského a karpatského stáří (Nehyba a Roetzel 1999). Vulkanoklastické sedimenty spodního miocénu jsou známy pouze z jihozápadní části karpatské předhlubně na Moravě, v ostatních částech karpatské předhlubně se v sedimentech spodního miocénu vyskytují pouze valouny bazických hornin v Ostravě-Jaklovci (Macoun et al. 1985). Nejmladší vulkanoklastické sedimenty karpatské předhlubně na Moravě mají podle Nehyby (1997) stanovené radiometrické stáří 16,2 \pm 2,1 Ma. Obdobné vulkanoklastické horizonty v Rakousku poskytly stáří $16,6 \pm 1,0 \mathrm{Ma}$ a 17,23 $\pm 0,18 \mathrm{Ma}$ (metodou ${ }^{40} \mathrm{Ar} /{ }^{39} \mathrm{Ar}$; Roetzel et al. 1999; Roetzel et al. 2014). Podle České stratigrafické komise (2011; www.geology.cz/stratigraphy/) lze geochronologicky datovat počátek období eggenburgu na 20,44 Ma a badenu na 15,97 Ma.

Výskyty spodnobadenských vulkanoklastik jsou relativně rozsáhlé, např́iklad v okolí Židlochovic jižně od Brna pokrývají dacitové vulkanické popely plochu (odvozenou ze starších vrtů Cf Žd 9, 10, 11, 12, 13, 27, 31) až $6,2 \mathrm{~km}^{2}$ (Slavík 1956) a dosahují mocnosti 4,5 až $7 \mathrm{~m}$. V oblasti Ostravska již Jurková a Tomšík (1959) zjistili výskyty dacitových tufitů minimálně ve 35 vrtech, místy i ve 2 až 3 polohách v jednom vrtu. Mocnosti tufitů zde kolísají od 0,1 m do 10,0 m.

\section{Geologická pozice studovaných lokalit}

Lokalita Ivančice-Réna leží v Jihomoravském kraji, v okrese Brno-venkov v blízkosti Ivančic (cca $1 \mathrm{~km}$ na JV od města), na katastrálním území Kounické Předměstí. Odkryv je situován zhruba $1000 \mathrm{~m}$ jv. od Památníku A. Muchy (N 495'48.0270“ E 16²3'16.4461“). Jedná se o denudační relikt sedimentů a vulkanoklastik situovaných v morfologické depresi na horninách brněnského masivu. Skalní podloží ložiska tvoří biotitický granodiorit (Pálenský et al. 1997). Na vyvřelé horniny transgredují sedimenty řazené bez biostratigrafických dokladů do eggenburgu/ottnangu, které obsahují vulkanoklastické sedimenty typu montmorillonitických jílů a bentonitů. Sedimenty jsou na bázi reprezentovány hrubozrnnými písčitými jíly s hojnou příměsí sutového materiálu, dále pokračují převážně písčité nebo prachovité jíly, místy $s$ příměsí křemenných valounů a stř̌edně zrnitými až jemnozrnnými křemennými nevápnitými písky. Maximální mocnost sedimentů eggenburgu/ottnangu zjištěná ve vrtech činí do $35 \mathrm{~m}$, bentonitové polohy do $5 \mathrm{~m}$, průměrná mocnost ložiskově významné suroviny činí 1,9 m (Čížek 1982). Bentonit směrem do podloží přechází do částečně bentonitizovaného tufitu.

Sedimenty spodního miocénu jsou v j. části ložiska přkekryty mladšími hrubě klastickými sedimenty spodního badenu v mocnosti do $20 \mathrm{~m}$. Tyto sedimenty jsou zastoupeny hrubozrnnými vápnitými písky s př́iměsí štěrku a sutového materiálu s polohami zeleného až hnědého, místy silně písčitého vápnitého jílu. Sedimenty spodního badenu jsou zčásti svahově porušené. Protože celková mocnost sedimentů miocénu narůstá směrem $\mathrm{kJ}$ proti sklonu svahu a poté tyto ostře vykliňují, předpokládáme, že se jedná o tektonicky zaklesnutou drobnou pánev, omezenou zlomy směru SZ-JV a JZ-SV (obr. 1a).

Druhá lokalita vulkanoklastik je situována v nárazovém břehu potoka Hlásenec v. od Lipníka nad Bečvou. Výchoz se nachází $2,0 \mathrm{~km}$ vsv. od zámku v Lipníku

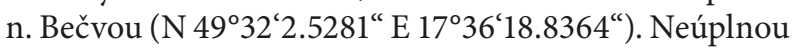
mocnost vulkanoklastik lze odhadnout na více než $8 \mathrm{~m}$ 


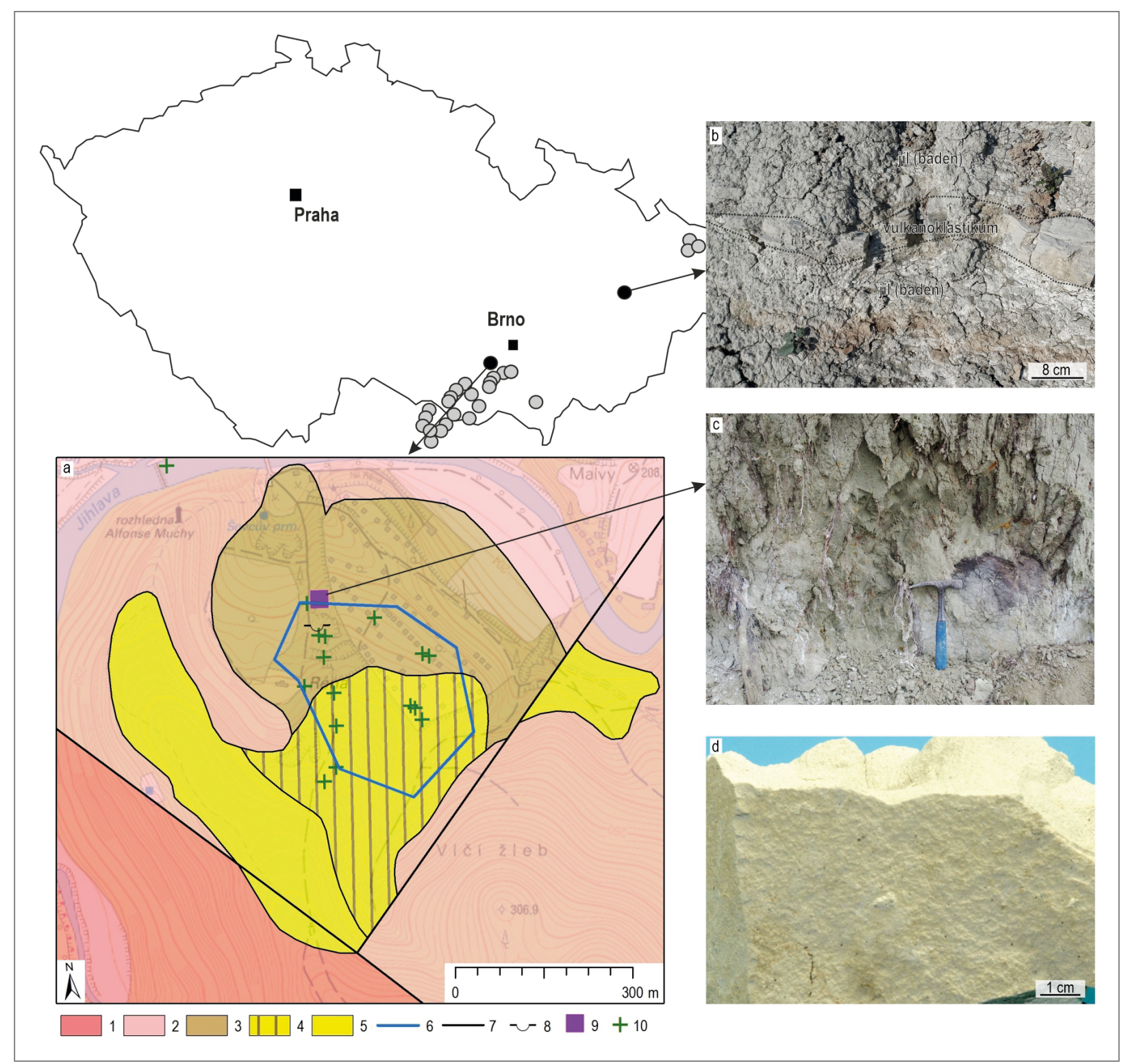

Obr. 1: Zjednodušená mapa České republiky s vyznačenými hlavními výskyty miocenních vulkanoklastik na Moravě (černá tečka studované lokality, šedá tečka lokality převzaty z literatury (Nehyba a Roetzel 1999; Nehyba a Stráník 2016; Jurková a Tomšík 1959). a) Odkrytá geologická mapa lokality Ivančice-Réna. 1 - biotitický až amfibol-biotitický granodiorit; 2 - biotitický granodiorit; 3 - sedimenty eggenburgu/ottnangu; 4 - sedimenty eggenburgu/ottnangu, zakrytá část sedimenty badenu; 5 - sedimenty badenu; 6 - ohraničení dobývacího prostoru a chráněného ložiskového území; 7 - zlomy; 8 - bývalá těžební jáma; 9 - místo odběru vzorku; 10 - lokalizace ložiskových vrtů. b) Poloha vulkanoklastik v jílech badenského stáří v těžební jámě u obce Jezernice. c) Odkryv montmorillonitických jílů na lokalitě Ivančice-Réna. d) Vulkanoklastická hornina s nízkým stupněm sekundárních přeměn z lokality Ivančice-Réna.

Fig. 1: Simplified map of the Czech Republic with main occurrences of Miocene volcanoclastics from Moravia (black dots refers to the studied localities, grey dots to of the localities taken from the literature (Nehyba and Roetzel 1999; Nehyba and Stráník 2016; Jurková and Tomšík 1959)). a) Simplified geological map of the study area Ivančice-Réna (without Quaternary). 1 - biotite to amphibol-biotite granodiorite; 2 - biotite granodiorite; 3 - Eggenburgian/Ottnangian sediments; 4 - Eggenburgian/Ottnangian sediments covered by Badenian deposits; 5 - Badenian sediments; 6 - mining claim and protected deposit area; 7 - faults; 8 - former exploitation pit; 9 - rock sample; 10 - boreholes location. b) Layer of the volcanoclastics hosted by the Badenian clay in a the exploitation pit near the village of Jezernice. c) Outcrop of montmorillonite clays at the locality Ivančice-Réna. d) Volcanoclastic rock with a low degree of secondary alteration from the locality Ivančice-Réna.

(LV022). Kontakt s podložím ani nadložím nebyl v zářezu pozorován. Lze předpokládat, že jde o horizont uvnitř vápnitých jílů badenu. Jíly spodního badenu s tufity byly v blízkosti zjištěny ložiskovým průzkumem pro těžbu cihlářské suroviny v Jezernici (Peloušek a Sirný 1997, 1998). Podle těchto průzkumných prací se vulkanoklastické sedimenty v okolí Lipníka nad Bečvou vyskytují až ve 3 samostatných polohách s maximální nepravou mocností 9,6 m ve vrtu GL-4 (Peloušek a Sirný 1997). Vrstvy sedimentů spodního badenu jsou v okolí Lipníka nad Bečvou šikmo ukloněné pod úhlem až $30^{\circ}$. Badenské stáří sedimentů v Jezernici a okolí bylo dále 
doloženo biostratigraficky pro paleomagnetickou studii karpatské předhlubně (Márton et al. 2011). Ryolitová vulkanoklastika byla dále zjištěna $\mathrm{v}$ nedalekých vrtech HV-1013, HV-1011 a 3MB8 v mocnosti přesahující $4 \mathrm{~m}$ (Bubík et al. 2018a). Podle uvedených průzkumných prací lze považovat výskyty kyselých vulkanoklastik v sedimentech badenu v této oblasti za regionální. Přímo $\mathrm{v}$ těžebně Jezernice byla zjištěna vrstva vulkanoklastik o mocnosti 1 až $7 \mathrm{~cm}\left(\mathrm{~N} 49^{\circ} 32^{\prime} 36.1^{\prime \prime} \mathrm{E} 17^{\circ} 36^{\prime} 41.7^{\prime \prime}\right)$ uvnitř jílů badenského stáří (HJG001c; obr. 1b).

\section{Terminologie jílových minerálů}

Při popisu produktů rozpadu vulkanických skel se často setkáváme s pojmem montmorillonit ve smyslu obecného krystalochemického vzorce $\left[(\mathrm{Na}, \mathrm{Ca})_{0.33}(\mathrm{Al}, \mathrm{Mg})_{2}\left(\mathrm{Si}_{4} \mathrm{O}_{10}\right)(\mathrm{OH})_{2} \cdot \mathrm{nH}_{2} \mathrm{O}\right]$. Zastoupení $\mathrm{Mg}$ a dalších prvků ve struktuře se přitom může výrazně měnit, což naznačuje definice Güvena (1988). Montmorillonit je podle této klasifikace dioktaedrický hlinitý smektit z minerální řady montmorillonit-beidellit s obecným vzorcem $\left(\mathrm{Al}_{2-\mathrm{y}} \mathrm{Mg}_{\mathrm{y}}\right)\left(\mathrm{Si}_{4-\mathrm{x}} \mathrm{Al}_{\mathrm{x}}\right) \mathrm{O}_{10}(\mathrm{OH})_{2}$ $\mathrm{E}_{\mathrm{x}+\mathrm{y}} \cdot \mathrm{nH}_{2} \mathrm{O}(\mathrm{E}=$ mezivrstevní kationty: $\mathrm{Na}, \mathrm{Ca}, \mathrm{K}), \mathrm{kde}$ $y>x$ (Güven 1988; Melka, Štastný 2014). Vzhledem $\mathrm{k}$ variabilitě studovaného materiálu $\mathrm{v}$ tomto článku používáme obecnější termín smektit, jehož složení se podle Schulze (2005) pohybují mezi třemi koncovými členy: Al-montmorillonit $\left[\mathrm{Na}_{0,2} \mathrm{Ca}_{0,1} \mathrm{Al}_{2} \mathrm{Si}_{4} \mathrm{O}_{10}(\mathrm{OH})_{2}\left(\mathrm{H}_{2} \mathrm{O}\right) 10\right]$, beidellit $\left[\mathrm{Na}_{0,5} \mathrm{Al}_{2,5} \mathrm{Si}_{3,5} \mathrm{O}_{10}(\mathrm{OH})_{2}\left(\mathrm{H}_{2} \mathrm{O}\right)\right]$ a nontronit $\left[\left(\mathrm{Ca}_{0,5}, \mathrm{Na}\right)_{0,3} \mathrm{Fe}^{3+}{ }_{2}(\mathrm{Si}, \mathrm{Al})_{4} \mathrm{O}_{10}(\mathrm{OH})_{2} \cdot \mathrm{nH}_{2} \mathrm{O}\right]$. Termín montmorillonit používáme pouze při popisu převzatých výsledků XRD a DTA (Čížek 1982; Krmíček a Čížek 1992; $\mathrm{XRD}=$ rentgenová difrakční analýza a DTA = diferenční termická analýza).

\section{Terénní a laboratorní práce}

Ryolitová vulkanoklastika prvního studovaného vzorku LV022 byla v průběhu geologického mapování odebrána v nárazovém břehu potoka Hlásenec v. od Lipníka nad Bečvou (Bubík et al. 2018a). Podnětem pro nové studium bentonitů na lokalitě Ivančice-Réna bylo rozhodnutí dnešního vlastníka těžebních práv na ložisku a pozemků pod ním (města Ivančice) z listopadu 2019 o sanaci celého prostoru ložiska. V říjnu 2021, kdy jsme odebírali vzorky hornin (vzorek BP402), již byl bentonit dostupný pouze v odvalech a ani stěnový výchoz montmorillonitických jílů (obr. 1c) v nadloží bentonitů (obr. 1d) nebyl dostupný. Terén s těžební jámou byl zarovnán pomocí navážek inertních materiálů - zemin a stavebních sutí. Vzhledem $\mathrm{k}$ nedostatku regionálně geologických informací z okolí ložiska byla oblast Rény $\mathrm{v}$ roce 2021 detailně geologicky zmapována $\mathrm{v}$ měřítku 1 : 10000 (obr. 1a). Detailní geologické mapování v měřítku 1 : 25000 zde totiž nebylo dokončeno a geologická situace této lokality je známa pouze z výsledků mapování v měřítku 1: 50000 (Pálenský et al. 1997) a z ložiskových průzkumů (např. Čížek 1982). Ložisko bentonitu bylo těženo od roku 1992 na základě výpočtů zásob Kolka et al. (1990) a Krmíčka - Čížka (1992). Vzhledem k vysokým nákladům a levnému dovozu suroviny ze zahraničí těžba rychle upadala, až původní těžební organizace zanikla. Pro detailní informace o vrtných pracích a ložiskových průzkumech na obou studovaných lokalitách odkazujeme na geodatabáze České geologické služby (www.geology. cz/mapove aplikace): SurIS, Vrtná prozkoumanost, ASGI.

Pro detailní studium byly zvoleny dva pevné masivní světlešedé vzorky (LV022 a BP402). Oba vzorky byly podrobeny petrografické analýze (polarizační mikroskop; elektronová mikrosonda) a celohorninové chemické analýze. Vzorek BP402 byl navíc analyzován rtg. difrakcí.

Pro petrografické studium byly vybrány vzorky s nejnižším stupněm sekundárních přeměn. Horniny byly studovány pomocí leštěného výbrusu. Studium výbrusů bylo provedeno na mikroskopu Nikon Eclipse ME600, mikrofotografie pořízeny kamerou Nikon DS-U3.

Mikrosondové analýzy jednotlivých minerálů a skla byly provedeny na vzorcích LV022 a BP402 ve spojených laboratořích elektronové mikroskopie a mikroanalýzy Masarykovy Univerzity a České geologické služby Brno na př́stroji Cameca SX-100 (operátor P. Gadas). Měření byla provedena ve vlnově disperzním modu (WDS) za následujících podmínek: urychlovací napětí $15 \mathrm{kV}$, proud paprsku 10 nebo $20 \mathrm{nA}$; průměr paprsku 1 nebo $4 \mu \mathrm{m}$. Pro pyroxeny a živce byly použity přírodní a syntetické standardy: Si, Al, K - sanidin, Na - albit, Fe - almandin (andradit pro živce), $\mathrm{Mn}$ - spessartin, $\mathrm{Mg}$ - pyrop, $\mathrm{Ca}$ - wollastonit, $\mathrm{Ti}$ - titanit, $\mathrm{P}$ - fluorapatit, $\mathrm{Y}-\mathrm{YPO}_{4}$, $\mathrm{Ni}-\mathrm{Ni}_{2} \mathrm{SiO}_{4}, \mathrm{Zn}$ - gahnit, $\mathrm{Cr}$ - chromit, $\mathrm{Sc}$ a V - $\mathrm{ScVO}_{4}$, $\mathrm{Ba}$ - baryt, $\mathrm{Sr}$ a S - $\mathrm{SrSO}_{4}, \mathrm{~F}$ - topaz, $\mathrm{Cl}$ - vanadinit. Data byla zpracována pomocí X-Phi Merlet korekce (Merlet 1994). Empirické vzorce živců a biotitů (chloritizovaných biotitů) byly přepočítány na 8 a 22 atomů kyslíku.

Dva vzorky s vysokým podílem jílových minerálů byly pomleté na analytickou jemnost a poté analyzovány v Acme Labs (Kanada) metodou FL202 (ICP-MS).

Vzorek BP402 byl homogenizován mletím v mlýnku McCrone (7 min/3 st.) v suspenzi etanolu. Vzorek byl analyzován rtg. difrakcí na práškovém rtg. difraktometru Bruker D8 Advance v Bragg-Brentanově uspořádání. Použito bylo CoKa záření a pozičně citlivého detektoru s detektorem Lynx Eye XE. Práškové vzorky pro rtg. difrakci byly připraveny metodou tzv. bočního plnění v plastových držácích. Difrakční záznam byl pořízen v úhlovém rozsahu $4-80^{\circ} 2 \Theta$ s krokem $0,015^{\circ}$ a načítacím časem 0,8 sek na krok. XRD analýzu provedl a vyhodnotil Dr. F. Laufek.

\section{Petrografie studovaných vulkanoklastik}

Bentonit $\mathrm{z}$ lokality Ivančice-Réna je bělavě šedá, místy zelenavě bílá masivní hornina s lasturnatým lomem. Sekundární procesy postihly vulkanoklastika z lokality Ivančice-Réna nerovnoměrně. Můžeme zde najít vzorky, kde jsou stále poměrně dobře patrné primární tvary stř́pků vulkanického skla a vedle nich se zde vyskytují montmorillonitické jíly. V některých vzorcích dokonce zcela převažuje jemně zrnitý smektit, jehož zastoupení v hornině dosahuje až 98 hm. \% (Čížek 1982; Krmíček a Čížek 1992). Tato hornina (bentonit) má velmi nízký obsah nejílových klastů nad 0,063 mm (do 19 hm. \%; 


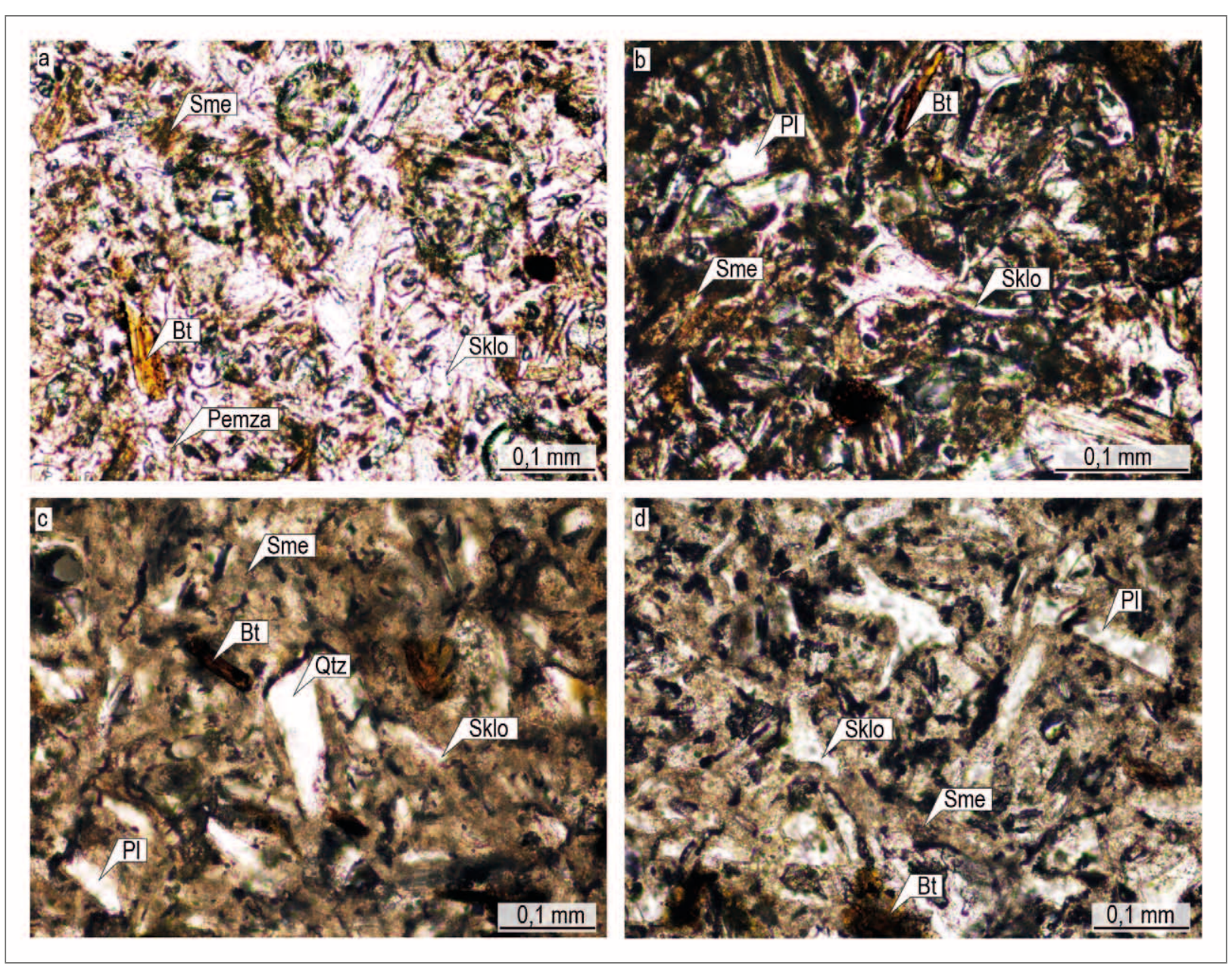

Obr. 2: Ryolitová vulkanoklastická hornina z lokality Ivančice-Réna (BP402, a-b) a Lipník nad Bečvou (LV022, c-d), optická mikroskopie, rovinně polarizované světlo (PPL). a) Krystaly biotitu, fragmenty pemzy a stř́pky skla obklopené základní hmotou složenou hlavně ze smektitu. b) Střípky vulkanického skla jsou částečně zatlačené smektitem (hojné opakní minerály: limonit a hematit). c) Xenomorfní úlomek křemene obklopený vulkanickým sklem částečně zatlačeným smektitem. d) Krystal biotitu a stř́pky vulkanického skla obklopené smektitem.

Fig. 2: Rhyolite volcanoclastic rock from the Ivančice-Réna (BP402, a-b) and Lipník nad Bečvou (LV022, c-d), optical microscopy, plane polarized light. a) Biotite crystals, fragments of pumices and glass shards surrounded by a matrix composed mainly of smectite. b) Shards of volcanic glass are partially replaced by smectite (abundant opaque minerals: limonite and hematite). c) Anhedral quartz surrounded by volcanic glass partially replaced by smectite. d) A biotite crystal and shards of volcanic glass surrounded by smectite.

Pavlík 1987). Místy bentonit přechází do jemnozrnného a prachovitého tufu až tufitu s hojnou př́měsí smektitu a se zbytky vulkanického skla. Hornina svou zrnitostí odpovídá vulkanickému popelu (obr. 2a) a obsahuje drobné úlomky pemzy stejně tak jako stř́ípky skla (délka pyroklastů až $0,3 \mathrm{~mm}$ ). Intenzita sekundárních přeměn je velmi variabilní, což je dobře patrné ve výbrusu. Ve studovaném vzorku vulkanoklastika $\mathrm{z}$ lokality Ivančice-Réna je část vulkanického skla přeměněna na smektit (53 mod. \%), avšak původní tvar střípků skla je často stále patrný (obr. 2b). Místy je také zřejmé, že společně se smektitem se vyskytuje opál. Často jsou dobře pozorovatelné relikty sklovitých klastů (38 mod. \%) a fragmenty minerálních zrn (9 mod. \%). Zbytky střípků vulkanického skla jsou ploché, nerovné nebo prohnuté a vznikly rozpadem napěněného vulkanického skla (některé úlomky mají průřez ve tvaru Y). Většinou hypautomorfní, často korodovaná minerální zrna jsou zastoupena křemenem, ternárním živcem $\left(\mathrm{Or}_{78} \mathrm{Ab}_{21} \mathrm{An}_{1}\right)$, biotitem a muskovitem. Ternární živec je lokálně postižen slabou sericitizací a často zakalen jílovými minerály. Biotit je automorfní a je částečně nahrazen hydrobiotitem, smektitem, limonitem nebo rutilem (obr. 2a). Místy jsou patrné lupínky světlých slíd, jejichž složení nebylo studováno, ale podle výsledku XRD analýzy se jedná o muskovit.

Ryolitová vulkanoklastika v. od Lipníka nad Bečvou jsou světle zelenošedá jemnozrnná (délka klastů až $0,2 \mathrm{~mm}$ ), místy páskovaná. Většina studované polohy je složena ze sypkého materiálu, podřízeně byla ve výchozu pozorována pevná, střepovitě rozpadavá hornina tuf (tufit). Ryolitová vulkanoklastika se skládají hlavně z ostrohranných střípků vulkanického skla (obr. 2c). Poměrně hojné jsou také úlomky krystalů živců a křemene (obr. $2 c, d)$, které jsou v hornině distribuovány nerovnoměrně. Vzácně se vyskytují také lupínky biotitu. Střípky vulkanického skla a úlomky pemzy (obr. 3a) nejeví známky 

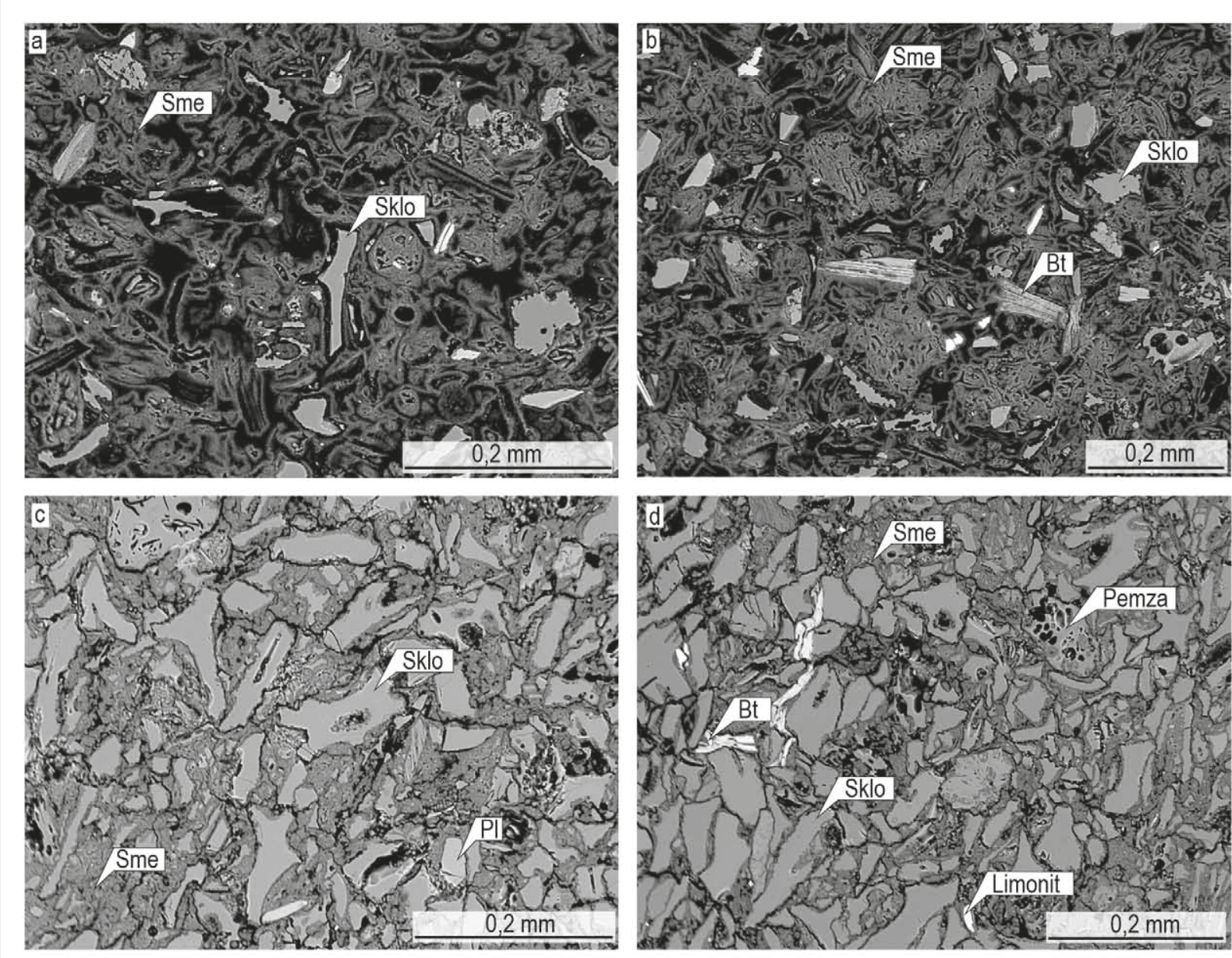

Obr. 3: BSE (backscattered-electron) mikrofotografie (P. Gadas) z ryolitových vulkanoklastických hornin z lokality Ivančice-Réna (BP402, a-b) a Lipník nad Bečvou (LV022, c-d). a) Fragmenty střípků vulkanického skla jsou nahrazeny smektitem (Sme). b) Biotit (Bt) mezi stř́pky vulkanického skla nahrazenými smektitem. c) Fragmenty pemzy a stř́pků vulkanického skla jsou částečně nahrazeny smektitem. d) Deformovaný idiomorfní biotit (Bt) mezi stř́ípky vulkanického skla (částečně nahrazen smektitem). Fig. 3: BSE (backscattered-electron) microphotographs (P. Gadas) of rhyolite volcanoclastic rocks from the Ivančice-Réna (BP402, a-b) and Lipník nad Bečvou (LV022, c-d). a) Fragments of pumices and glass shards are partially replaced by smectite. b) Biotite (Bt) among glass shards replaced by smectite. c) Fragments of glass shards are replaced by smectite. d) Deformed idiomorphic biotite $(\mathrm{Bt})$ among glass shards partially replaced by smectite.

spečení a svým chemickým složením odpovídají ryolitu. Studovaná vulkanoklastická hornina z velké ćásti sestává z pemzy a stř́ípků vulkanického skla (42 mod. \%). Sekundární minerály (hlavně smektit) tvoří 47 mod. \%, zatímco minerální fáze jako je plagioklas, křemen a biotit, tvoří 11 mod. \%. Vulkanické sklo často nese na povrchu známky sekundárních přeměn na jílové minerály (obr. 3a, b). Jílové minerály také převažují v základní hmotě mezi jednotlivými klasty (obr. 3a, b). Drobná hypautomorfně omezená zrna vulkanického křemene mají velikost $0,2 \mathrm{~mm}$. Dále jsou př́tomny automorfně až hypautomorfně omezené lišty obou druhů živců (obr. 2d), draselný živec obsahuje albitovou komponentu (tab. 1; $\mathrm{Or}_{62-63} \mathrm{Ab}_{32-33}$ ), bazicita plagioklasu odpovídá andezínu $\left(\mathrm{Ab}_{59-60}\right)$. Živce jsou místy sekundárně přeměněné na směs jílových mineráli̊. V hornině jsou také př́tomny lupínky biotitu místy baueritizované nebo chloritizované (tab. 2; 4,9-6,2 hm. \% $\left.\mathrm{K}_{2} \mathrm{O} ; \mathrm{xMg}=\mathrm{MgO} / \mathrm{FeO}+\mathrm{MgO}=0,29-0,31\right)$.

\section{Výsledky XRD difrakce}

XRD záznam výrazně bentonitizovaného vzorku BP402 potvrdil převahu smektitu. Podle difrakčního záznamu se patrně jedná o smektit (elektronická př́loha I), což je v dobrém souladu se zjištěným chemickým složením vzorku. Dále byly zjištěny plagioklasy v obsazích až $10 \mathrm{hm}$. \%. Křemen a muskovit jsou př́tomny v podružném množství do cca $3 \mathrm{hm}$. \%.

\section{Chemické složení studovaných vulkanoklastik}

Oba studované vzorky vulkanoklastik můžeme klasifikovat jako kyselé horniny, jejichž chemické složení se však mírně liší (obr. 4a). Vzorek z lokality Lipník nad Bečvou (LV22) se vyznačuje vysokým obsahem $\mathrm{SiO}_{2}$ $(70,5 \mathrm{hm} . \%)$ stejně jako poměry $\mathrm{Zr} / \mathrm{Ti}(0,17)$ a Nb/Y $(0,4)$, což je typické pro vápenato-alkalické ryolity. Obsahy $\mathrm{SiO}_{2}(52,9 \mathrm{hm}$. \%) řadí vzorek z lokality Ivančice-Réna (BP402) $\mathrm{k}$ vápenato-alkalickým dacitům (obr. 4a), avšak poměry $\mathrm{Zr} / \mathrm{Ti}(0,16)$ a $\mathrm{Nb} / \mathrm{Y}(0,5)$ jsou $\mathrm{v}$ podstatě stejné 
Tab. 1: Reprezentativní analýzy chemického složení živců ze studovaných vulkanoklastických hornin LV022 (25-33) a BP402 (6). Empirický vzorec přepočítány na 8 atomů kyslíku.

Tab. 1: Representative compositions of the feldspars from the studied volcanoclastic rock LV022 (25-33) and BP402 (6). Formula calculations are based on 8 oxygen.

\begin{tabular}{|l|c|c|c|c|c|}
\hline Č́íslo & $\mathbf{2 5}$ & $\mathbf{2 6}$ & $\mathbf{3 2}$ & $\mathbf{3 3}$ & $\mathbf{6}$ \\
\hline $\mathrm{SiO}_{2}$ & 58,72 & 64,55 & 65,81 & 58,91 & 65,01 \\
\hline $\mathrm{P}_{2} \mathrm{O}_{5}$ & 0,02 & 0,02 & 0,00 & 0,04 & 0,04 \\
\hline $\mathrm{Al}_{2} \mathrm{O}_{3}$ & 26,75 & 19,45 & 19,04 & 26,27 & 18,84 \\
\hline $\mathrm{FeO}$ & 0,20 & 0,11 & 0,07 & 0,18 & 0,09 \\
\hline $\mathrm{CaO}$ & 8,65 & 0,20 & 0,16 & 7,99 & 0,21 \\
\hline $\mathrm{SrO}$ & 0,07 & 0,04 & 0,08 & 0,00 & 0,16 \\
\hline $\mathrm{BaO}$ & 0,01 & 2,31 & 0,68 & 0,01 & 0,90 \\
\hline $\mathrm{Na}_{2} \mathrm{O}$ & 7,03 & 3,60 & 3,59 & 7,03 & 2,31 \\
\hline $\mathrm{K}_{2} \mathrm{O}$ & 0,25 & 10,91 & 11,44 & 0,43 & 12,69 \\
\hline $\mathrm{Celkem}$ & 101,62 & 98,83 & 100,11 & 100,85 & 99,19 \\
\hline $\mathrm{Si}$ & 2,590 & 2,945 & 2,980 & 2,615 & 2,979 \\
\hline $\mathrm{Al}$ & 1,391 & 1,046 & 1,016 & 1,374 & 1,017 \\
\hline $\mathrm{Fe}{ }^{3+}$ & 0,008 & 0,004 & 0,003 & 0,007 & 0,003 \\
\hline $\mathrm{Ca}$ & 0,404 & 0,010 & 0,008 & 0,375 & 0,010 \\
\hline $\mathrm{Sr}$ & 0,002 & 0,001 & 0,002 & 0,000 & 0,004 \\
\hline $\mathrm{Ba}$ & 0,000 & 0,041 & 0,012 & 0,000 & 0,016 \\
\hline $\mathrm{Na}$ & 0,601 & 0,319 & 0,315 & 0,605 & 0,205 \\
\hline $\mathrm{K}$ & 0,014 & 0,635 & 0,661 & 0,024 & 0,742 \\
\hline $\mathrm{An}$ & 40 & 1 & 1 & 37 & 1 \\
\hline $\mathrm{Ab}$ & 59 & 33 & 32 & 60 & 21 \\
\hline $\mathrm{Or}$ & 1 & 66 & 67 & 2 & 78 \\
\hline & & & & &
\end{tabular}

Tab. 2: Reprezentativní analýzy chemického složení alterovaného biotitu ze studované vulkanoklastické horniny LV022. Empirický vzorec byl přepočítán na 22 atomů kyslíku [OH bylo vypočteno jako $\mathrm{OH}=4-(\mathrm{Cl}+\mathrm{F})]$.

Tab. 2: Representative compositions of altered biotite from the studied volcanoclastic rock LV022. Formula calculations are based on 22 oxygen $[\mathrm{OH}$ is calculated by $\mathrm{OH}=4-(\mathrm{Cl}+\mathrm{F})]$.

\begin{tabular}{|l|c|c|l|c|c|}
\hline Č́slo & $\mathbf{3 0}$ & $\mathbf{3 1}$ & Č́slo & $\mathbf{3 0}$ & $\mathbf{3 1}$ \\
\hline $\mathrm{SiO}_{2}$ & 36,63 & 38,12 & $\mathrm{Si}$ & 6,159 & 6,251 \\
\hline $\mathrm{TiO}_{2}$ & 3,39 & 3,53 & ${ }^{\mathrm{I}} \mathrm{Al}$ & 1,841 & 1,749 \\
\hline $\mathrm{Al}_{2} \mathrm{O}_{3}$ & 11,37 & 11,56 & ${ }^{\mathrm{V}} \mathrm{Al}$ & 0,411 & 0,486 \\
\hline $\mathrm{FeO}$ & 23,03 & 23,85 & $\mathrm{Ti}$ & 0,429 & 0,435 \\
\hline $\mathrm{MnO}$ & 0,18 & 0,29 & $\mathrm{Fe}$ & 3,238 & 3,271 \\
\hline $\mathrm{MgO}$ & 5,83 & 5,46 & $\mathrm{Mn}$ & 0,026 & 0,040 \\
\hline $\mathrm{CaO}$ & 0,20 & 0,54 & $\mathrm{Mg}$ & 1,461 & 1,335 \\
\hline $\mathrm{Na}_{2} \mathrm{O}$ & 0,12 & 0,15 & $\mathrm{Ca}$ & 0,037 & 0,095 \\
\hline $\mathrm{K}_{2} \mathrm{O}$ & 6,19 & 4,88 & $\mathrm{Na}$ & 0,040 & 0,047 \\
\hline $\mathrm{F}$ & 0,36 & 0,35 & $\mathrm{~K}$ & 1,327 & 1,022 \\
\hline $\mathrm{Cl}$ & 0,29 & 0,24 & $\mathrm{OH}$ & 3,726 & 3,752 \\
\hline $\mathrm{H}_{2} \mathrm{O}^{*}$ & 3,32 & 3,43 & $\mathrm{~F}$ & 0,193 & 0,183 \\
\hline $\mathrm{O}=\mathrm{F}, \mathrm{Cl}$ & 0,22 & 0,20 & $\mathrm{Cl}$ & 0,081 & 0,065 \\
\hline $\mathrm{Celkem}$ & 90,693 & 92,203 & $\mathrm{Celkem}$ & 18,969 & 18,730 \\
\hline
\end{tabular}

jako u předchozího vzorku. Variabilní je také zastoupení dalších hlavních prvků (tab. 3) jako je například vyšší zastoupení $\mathrm{Al}_{2} \mathrm{O}_{3}$ (15,51 vs. 12,28 hm. \%), $\mathrm{Fe}_{2} \mathrm{O}_{3}(3,44$ vs. $1,45 \mathrm{hm}$. $\%), \mathrm{MgO}(3,56$ vs. $0,79 \mathrm{hm}$. $\%)$ a $\mathrm{CaO}(2,40$ vs. $1,22 \mathrm{hm}$. \%) ve vzorku BP402. Obsahy $\mathrm{K}_{2} \mathrm{O}(2,1$ a 0,7 hm. \%) a $\mathrm{Na}_{2} \mathrm{O}(2,1$ a 0,6 hm. \%) v bentonitech (tab. 3) jsou nižší než v primárním vulkanickém sklu $\left(\mathrm{K}_{2} \mathrm{O}=2,7\right.$ až 4,1 hm. \%) a $\mathrm{Na}_{2} \mathrm{O}$ (1,9 až 3,1 hm. \%).
Na základě poměrně nízkého obsahu Rb (27 a 91 ppm; tab. 4), Y (28 a 29 ppm), Yb (2,8 a 3,2 ppm), Nb (12 a $14 \mathrm{ppm})$ a Ta (1,1 a 1,2 ppm) se patrně jedná o ryolit pocházející z geotektonického prostředí vulkanického oblouku (Pearce et al. 1984; Schandl a Gorton 2002). Tvar křivek REE normalizovaných chondritem (Boynton 1984; obr. 4b) je charakterizován klesajícím trendem v oblasti LREE $\left(\mathrm{La}_{\mathrm{N}} / \mathrm{Sm}_{\mathrm{N}}=3,1\right.$ a 3,7$)$, poměrně plochou křivkou v oblasti HREE (obr. 4b) a výraznou zápornou Eu anomálií $\left(\mathrm{Eu} / \mathrm{Eu}^{*}=0,28\right.$ a 0,47). Obsahy stopových prvků jsou většinou velmi blízké hodnotám uváděným pro svrchní kontinentální kůru podle Taylora a McLennana (1995) (obr. 4c). Patrné jsou slabé záporné anomálie v obsazích Sr, P, Ti a Tb. Celkové chemické složení vulkanoklastik z obou lokalit (Lipník nad Bečvou - LV22, Ivančice-Réna - BP402) je oproti chemickému složení vulkanického skla z těchto hornin posunuto směrem k sekundárním jílovým minerálům (smektitu, obr. 4d-f).

\section{Diskuze}

Z hlediska možného prrínosu vulkanoklastického materiálu jak do spodnomioceního, tak do spodnobadenského prostoru karpatské předhlubně, lze uvažovat o karpato-pannonském prostoru. $\mathrm{V}$ př́ípadě spodnomiocenních vulkanoklastik lze předpokládat zdroje z oblasti jižního Slovenska, pohoří Mátra, případně ze vzdálenějších zdrojů z oblastí Mecseku a jižního Mad’arska (Pécskay et al. 2006). Pro lokality spodnobadenské příchází jako možný zdroj v úvahu oblast štýrské pánve, Burgenlandska, pohoří Bükk, Mecsek, Cserhát-Mátra a středního Mad’arska (Pécskay et al. 2006). Z tohoto hlediska zdroje vulkanoklastického materiálu je důležitá chemická charakteristika minerálních zrn. Minerály se ve studovaných vulkanoklastických horninách vyskytují většinou jako ostrohranná, často korodovaná zrna (obr. 3b-d). Vzácně je patrné, že jsou xenomorfní krystaly částečně obklopeny sklem. Tyto texturní znaky jsou typické pro kyselý vulkanický popel a nenaznačují, že by se ve vulkanoklastickém materiálu vyskytovalo větší množství sedimentárních klastů. Zajímavá je variabilita živců ve vzorku vulkanoklastika od Lipníka nad Bečvou, kde se vyskytují draselné živce $\left(\mathrm{Or}_{62-63} \mathrm{Ab}_{32-33}\right)$ společně $s$ andezínem $\left(\mathrm{Ab}_{59-60}\right)$, ve druhém vzorku $\mathrm{z}$ lokality Ivančice-Réna byl nalezen hlavně ternární živec $\left(\mathrm{Or}_{78} \mathrm{Ab}_{21} \mathrm{An}_{1}\right)$. Tyto rozdíly mohou souviset s rozdílnou intenzitou sekundárních alterací (živce s vyšší bazicitou podléhají snáze rozpadu na sekundární minerály), nemůžeme však také vyloučit variabilní chemické složení $\mathrm{v}$ důsledku odlišného zdroje magmatu (např. mingling kyselého magmatu s bazickým). Studované plagioklasy $\left(\mathrm{Ab}_{59-60}\right)$ a biotity (vysoké $\mathrm{xMg}=0,29$ až 0,31$)$ a $\mathrm{TiO}_{2}=$ 3,4 až 3,5 hm. \%; tab. 2) mají podobné složení jako tyto minerály obsažené ve slovenských obsidiánech (Kohut et al. 2019). Podle těchto autorů vykazují plagioklasy v obsidiánech poměrně výraznou zonálnost (ve středech $A b_{11-67}$ a na okrajích $\mathrm{Ab}_{69-81}$ ) a biotity jsou charakterizovány xMg od 0,32 do 0,43 a vysokými obsahy $\mathrm{TiO}_{2}$ (3,2 až 4,6 hm. \%).

Oba studované vzorky vulkanoklastických hornin můžeme klasifikovat jako vulkanický popel ryolitového 

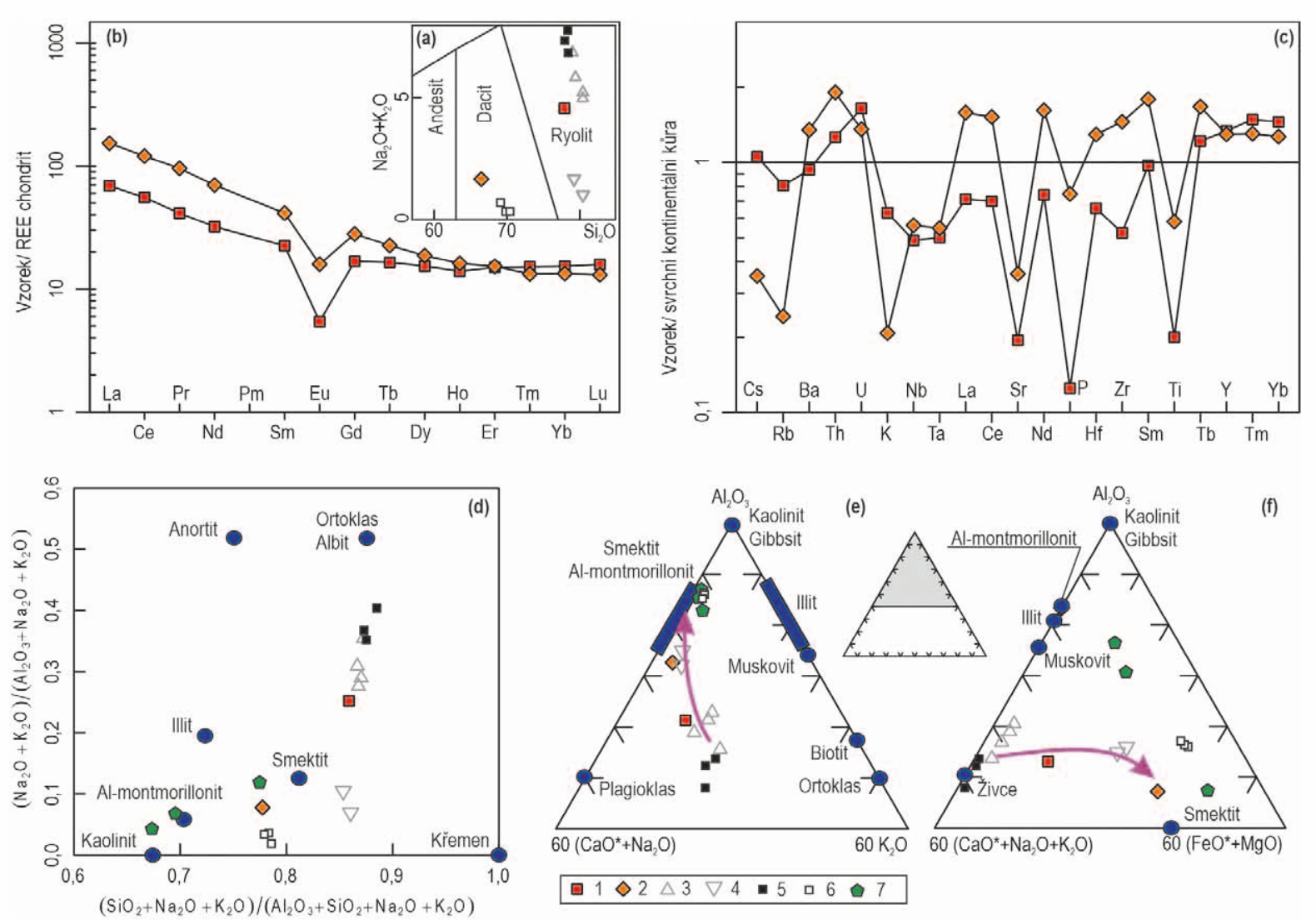

Obr. 4: Chemické složení vulkanoklastických hornin z obou studovaných lokalit (BP402, LV022), vulkanického skla a jílových minerálů z Lipníku nad Bečvou. a) diagram celkových alkálií $\left(\mathrm{Na}_{2} \mathrm{O}+\mathrm{K}_{2} \mathrm{O}\right.$ ) versus $\mathrm{SiO}_{2}$ (upraveno podle LeBas et al. 1986); b) chondritem normalizované vzory prvků vzácných zemin (REE) (hodnoty pro normalizaci jsou převzaty z Boyntona 1984); c) víceprvkové variační diagramy normalizované na svrchní kontinentální kůru [hodnoty pro normalizaci podle McDonough a Sun (1995)]; d) $\left(\mathrm{Na}_{2} \mathrm{O}+\mathrm{K}_{2} \mathrm{O}\right) /\left(\mathrm{Al}_{2} \mathrm{O}_{3}+\mathrm{Na}_{2} \mathrm{O}+\mathrm{K}_{2} \mathrm{O}\right)$ vs. $\left(\mathrm{SiO}_{2}+\mathrm{Na}_{2} \mathrm{O}+\mathrm{K}_{2} \mathrm{O}\right) /\left(\mathrm{SiO}_{2}+\mathrm{Al}_{2} \mathrm{O}_{3}+\mathrm{Na}_{2} \mathrm{O}+\mathrm{K}_{2} \mathrm{O}\right)$ diagram podle $\mathrm{Kronberga}$ a Nesbitta (1981); e, f) ternární diagramy: $\mathrm{Al}_{2} \mathrm{O}_{3}-\left(\mathrm{CaO}+\mathrm{Na}_{2} \mathrm{O}\right)-\mathrm{K}_{2} \mathrm{O}$ a Al $\mathrm{O}_{3}-\left(\mathrm{CaO}^{*}+\mathrm{Na}_{2} \mathrm{O}+\mathrm{K}_{2} \mathrm{O}\right)-(\mathrm{FeO} *+\mathrm{MgO})$ podle Nesbitta a Younga (1982) a Nesbitta et al. (1996). $\mathrm{FeO}^{\star}=$ všechno železo přepočteno na $\mathrm{FeO} ; \mathrm{CaO}^{\star}=$ obsah $\mathrm{CaO}$ v silikátech. Vzorky: (1) vulkanoklastická hornina Lipník nad Bečvou (LV022), (2) vulkanoklastická hornina Ivančice-Réna (BP402), (3) vulkanické sklo (LV022), (4) jílové minerály (LV022), (5) vulkanické sklo (BP402), (6) jílové minerály (BP402), (7) průměrné složení minerálů montmorillonit-beidellitové skupiny vzniklých alterací kyselých hornin na třech lokalitách v Maroku (Ddani et al. 2005).

Fig. 4: Chemical composition of the volcanoclastic rocks from both studied localities (BP402, LV022), volcanic glass and clay minerals from Lipník nad Bečvou. a) total alkalis $\left(\mathrm{Na}_{2} \mathrm{O}+\mathrm{K}_{2} \mathrm{O}\right.$ ) versus $\mathrm{SiO}_{2}$ diagram (modified from LeBas et al. 1986); b) chondrite-normalised rare earth element (REE) patterns (the values for normalization are based on Boynton 1984); c) upper Continental Crust-normalised multi-element variation diagrams [the values for normalization are based on McDonough and Sun (1995)]; d) $\left(\mathrm{Na}_{2} \mathrm{O}+\mathrm{K}_{2} \mathrm{O}\right) /\left(\mathrm{Al}_{2} \mathrm{O}_{3}+\mathrm{Na}_{2} \mathrm{O}+\mathrm{K}_{2} \mathrm{O}\right)$ vs. $\left(\mathrm{SiO}_{2}+\mathrm{Na}_{2} \mathrm{O}+\mathrm{K}_{2} \mathrm{O}\right) /\left(\mathrm{SiO}_{2}+\mathrm{Al}_{2} \mathrm{O}_{3}+\mathrm{Na}_{2} \mathrm{O}+\mathrm{K}_{2} \mathrm{O}\right)$ diagram given by Kronberg and Nesbitt (1981); e, f) the ternary diagrams: $\mathrm{Al}_{2} \mathrm{O}_{3}-\left(\mathrm{CaO}+\mathrm{Na}_{2} \mathrm{O}\right)-\mathrm{K}_{2} \mathrm{O}$ and $\mathrm{Al}_{2} \mathrm{O}_{3}-\left(\mathrm{CaO}^{\star}+\mathrm{Na}_{2} \mathrm{O}+\mathrm{K}_{2} \mathrm{O}\right)-(\mathrm{FeO} *+\mathrm{MgO})$ given by Nesbitt and Young (1982) and Nesbitt et al. (1996). $\mathrm{FeO}^{*}=$ total iron oxides; $\mathrm{CaO}^{*}=\mathrm{CaO}$ in silicate-bearing minerals only. Samples: (1) volcanoclastic rock Lipník nad Bečvou (LV022), (2) volcanoclastic rock Ivančice-Réna (BP402), (3) volcanic glass (LV022), (4) clay minerals (LV022), (5) volcanic glass (BP402), (6) clay minerals (BP402), (7) average composition of minerals of the montmorillonite-beidellite series formed by alterations of acidic rocks in three localities in Morocco (Ddani et al. 2005).

složení na základě obsahu nemobilních stopových prvků ( $\mathrm{Zr}, \mathrm{Ti}, \mathrm{Nb}, \mathrm{Y})$ a na základě chemického složení zachovalého vulkanického skla. Vulkanoklastika nenesou známky sekundárního transportu a nevykazují známky výraznějšího zrnitostního vytř́idění. $V$ obou případech se tedy pravděpodobně primárně jednalo o spad vulkanického popela do vodního prostřední.

Vzorek materiálu na chemickou analýzu odebraný z lokality Ivančice-Réna (BP402) je postižen intenzivnější sekundární přeměnou ve srovnání se vzorkem $\mathrm{z}$ lokality Lipník nad Bečvou (LV022). Přeměna postihuje hlavně vulkanické sklo a biotit. $\mathrm{V}$ důsledku sekundárních přeměn se mění zastoupení některých mobilních chemických prvků a hodnoty LOI (9,4 a 20,2 hm. \%), což ovlivňuje chemické složení celé horniny (obr. 4a, c; např. $\mathrm{Si}, \mathrm{K}, \mathrm{Na}, \mathrm{Rb}, \mathrm{Cs})$. V diagramech $4 \mathrm{~d}-\mathrm{f}$ je patrné, že celkové chemické složení vulkanoklastické horniny LV022 leží mezi chemickým složením primárního vulkanického skla a chemickým složením jílových minerálů, které vznikají jeho rozpadem (smektit). Z diagramů $4 \mathrm{e}-\mathrm{f}$ je zároveň zřejmé, že dominantním minerálem není koncový člen minerální řady Al-montmorillonit-beidellit $\left[\mathrm{Na}_{0,2} \mathrm{Ca}_{0,1} \mathrm{Al}_{2} \mathrm{Si}_{4} \mathrm{O}_{10}(\mathrm{OH})_{2}\left(\mathrm{H}_{2} \mathrm{O}\right)_{10}\right]$, ale jedná se spíše o Mg-Al-Fe smektit. V diagramu $4 \mathrm{~d}$ je patrné, 
Tab. 3: Obsahy hlavních prvků vulkanoklastických hornin (vulk.), vulkanického skla (sklo) a smektitu (Sme).

Tab. 3: Contents of major elements of the volcanoclastic rocks (vulk.), volcanic glass (sklo) and smectite (Sme).

\begin{tabular}{|l|c|c|c|c|c|c|c|c|c|c|c|c|}
\hline Vzorek & LV022 & BP402 & 1LV022 & 2LV022 & 3LV022 & 4LV022 & 5BP402 & 6BP402 & 5LV022 & 6LV022 & 2BP402 & 4BP402 \\
\hline Hornina & vulk. & vulk. & sklo & sklo & sklo & sklo & sklo & sklo & Sme & Sme & Sme & Sme \\
\hline $\mathrm{SiO}_{2}$ & 70,49 & 52,87 & 74,955 & 74,297 & 74,513 & 74,038 & 74,64 & 75,312 & 68,221 & 66,411 & 59,257 & 59,602 \\
\hline $\mathrm{Al}_{2} \mathrm{O}_{3}$ & 12,28 & 15,51 & 11,902 & 11,79 & 12,239 & 11,982 & 12,047 & 11,972 & 11,962 & 10,923 & 16,891 & 16,76 \\
\hline $\mathrm{Fe}_{2} \mathrm{O}_{3} \mathrm{t}$ & 1,45 & 3,44 & - & - & - & - & - & - & - & - & - & - \\
\hline $\mathrm{FeOt}$ & - & - & 0,815 & 0,852 & 0,857 & 0,796 & 1,274 & 1,351 & 1,325 & 1,312 & 3,767 & 3,973 \\
\hline $\mathrm{MgO}$ & 0,79 & 3,56 & 0,022 & 0,017 & 0,022 & 0,031 & 0,052 & 0,035 & 1,671 & 1,538 & 3,845 & 4,053 \\
\hline $\mathrm{CaO}$ & 1,22 & 2,4 & 0,553 & 0,542 & 0,584 & 0,554 & 0,71 & 0,845 & 1,515 & 1,447 & 1,094 & 0,985 \\
\hline $\mathrm{Na}_{2} \mathrm{O}$ & 2 & 0,61 & 2,543 & 2,119 & 2,781 & 1,92 & 3,087 & 2,5 & 0,603 & 0,254 & 0,253 & 0,28 \\
\hline $\mathrm{K}_{2} \mathrm{O}$ & 2,12 & 0,7 & 3,994 & 2,709 & 2,716 & 2,669 & 3,978 & 4,104 & 0,804 & 0,562 & 0,339 & 0,313 \\
\hline $\mathrm{TiO}_{2}$ & 0,1 & 0,29 & 0,028 & 0,02 & 0,034 & 0,014 & 0,071 & 0,058 & 0,047 & 0,089 & 0,315 & 0,364 \\
\hline $\mathrm{P}_{2} \mathrm{O}_{5}$ & 0,02 & 0,12 & 0,00 & 0,00 & 0,009 & 0,00 & 0,00 & 0,00 & 0,00 & 0,00 & 0,00 & 0,00 \\
\hline $\mathrm{MnO}$ & 0,03 & 0,03 & 0,059 & 0,054 & 0,052 & 0,059 & 0,04 & 0,013 & 0,003 & 0,004 & 0,017 & 0,041 \\
\hline $\mathrm{Cr}_{2} \mathrm{O}_{3}$ & $<0,002$ & 0,002 & 0,005 & 0,000 & 0,000 & 0,022 & 0,011 & 0,038 & 0,008 & 0,007 & 0,000 & 0,000 \\
\hline $\mathrm{LOI}$ & 9,4 & 20,2 & 5,124 & 7,6 & 6,193 & 7,915 & 4,09 & 3,772 & 13,841 & 17,453 & 14,222 & 13,629 \\
\hline $\mathrm{Celkem}$ & 100 & 99,9 & 100 & 100 & 100 & 100 & 100 & 100 & 100 & 100 & 100 & 100 \\
\hline
\end{tabular}

že chemické složení směsi jílových minerálů leží mezi smektitem a křemenem, což naznačuje prríměs opálu nebo některého dalšího minerálu ze skupiny $\mathrm{SiO}_{2}$. Chemické složení mikrosondových analýz tedy naznačuje, že jde o směs, v níž se kromě dominantního smektitu vyskytuje v malém množství také opál. Nemůžeme vyloučit ani př́ítomnost jílových minerálů bohatých $\mathrm{Fe}$ a $\mathrm{Mg}$ [např́klad nontronit případně i saponit $=\mathrm{Ca}_{0,25}(\mathrm{Mg}, \mathrm{Fe})_{3}\left((\mathrm{Si}, \mathrm{Al})_{4} \mathrm{O}_{10}\right)$ $(\mathrm{OH})_{2} \cdot n\left(\mathrm{H}_{2} \mathrm{O}\right)$; Iijima 1978; Christidis a Huff 2009; García-Romero et al. 2019]. Chemické složení vulkanoklastika z lokality Ivančice-Réna (LV022) se blíží v těchto diagramech ještě více smektitu, což naznačuje, že ve vzorku tento minerál převažuje. Dominanci tohoto minerálu navíc potvrdila XRD analýza.

Na detailních BSE snímcích je patrné zatlačování vulkanického skla drobnými lupínky smektitu, které jsou vyvinuty na celém povrchu stř́ípko̊ skla a někdy vyplňují i drobné vesikuly v tomto skle (obr. 3). Vznik smektitu patrně souvisí s cirkulací podzemní nebo diagenetické vody. Při interakci těchto roztoků s vulkanickým sklem vznikají jílové minerály, které spotřebují většinu uvolněného oxidu křemičitého a hliníku, ale ponechávají $\mathrm{v}$ roztoku více mobilní prvky jako je například Si, K, Na, $\mathrm{Ca}, \mathrm{Mg}$ nebo Fe (např. Shiraki et al. 1987; Fiore et al. 1999; Kadir et al. 2019).

Chemické složení jílových minerálů (smektitů) $\mathrm{z}$ obou studovaných lokalit je v diagramech $4 \mathrm{~d}-\mathrm{f}$ situováno poměrně blízko od průměrného chemického složení jílových minerálů, které vznikly rozpadem kyselých vulkanických hornin (Ddani et al. 2005). Posun mikrosondových analýz směrem $\mathrm{k} \mathrm{SiO}_{2}$ (obr. $4 \mathrm{~d}$ ) poměrně dobře koresponduje s přítomností malého množství opálu, který je patrný v optickém mikroskopu a impregnuje produkty rozpadu vulkanického skla. Př́tomnost malého množství novotvořeného opálu, eventuelně i dalších modifikací $\mathrm{SiO}_{2}$ ve studovaných produktech sekundárních přeměn ryolitového vulkanického skla souvisí s charakteristikami otevřeného systému, $\mathrm{v}$ němž smektit vznikal. Z experimentálních studií, simulujících smektitizaci vulkanického skla, je totiž patrné, že šance na srážení volného $\mathrm{SiO}_{2}$ klesá s rostoucím průtokem vodných roztoků. Naproti tomu vyluhování nemobilního Al není významné (Daux et al. 1997). Proto je často vznik vysoce kvalitních bentonitů z kyselých hornin spojován s oblastmi s výrazným termálním gradientem, kde může docházek k cirkulaci podzemní vody (např. Christidis a Huff 2009). V takových systémech jsou alkalické kovy a Si vyluhovány z vulkanického skla a v podobě hydrotermálních roztoků mizí ze systému, což zabraňuje vzniku opálu a zeolitů. Tento model však není vhodný pro námi studované výskyty vulkanoklastik, které se usadily v oblastech s relativně nízkým termálním gradientem (v. okraj Českého masivu). Výrazná migrace fluid však mohla probíhat v souvislosti s intenzivním zvětráváním, které předcházelo badenské transgresi (Krystek 1981), což je ale možné pouze u lokality Ivančice-Réna (BP402). Pro takový proces by byla typická stratifikace sekundárních přeměn vzhledem $\mathrm{k}$ paleoreliéfu (s hloubkou se obvykle mění chemické složení podzemních vod včetně $\mathrm{pH}$ ). Nehomogenitu procesů sekundárních přeměn potvrzují dříve publikované výsledky DTA a XRD studia vzorků z lokality Ivančice-Réna (Čížek 1980).
Tab. 4: Obsahy stopových prvků vulkanoklastických hornin.

Tab. 4: Contents of trace elements of the volcanoclastic rocks.

\begin{tabular}{|l|c|c|}
\hline Vzorek & LV022 & BP402 \\
\hline $\mathrm{Ba}$ & 514 & 742 \\
\hline $\mathrm{Cs}$ & 3,9 & 1,3 \\
\hline $\mathrm{Hf}$ & 3,8 & 7,5 \\
\hline $\mathrm{Nb}$ & 12,2 & 14,0 \\
\hline $\mathrm{Rb}$ & 90,5 & 27,1 \\
\hline $\mathrm{Sr}$ & 68,0 & 125,4 \\
\hline $\mathrm{Ta}$ & 1,1 & 1,2 \\
\hline $\mathrm{Th}$ & 13,5 & 20,4 \\
\hline $\mathrm{U}$ & 4,6 & 3,8 \\
\hline $\mathrm{Zr}$ & 99,3 & 276,5 \\
\hline $\mathrm{Y}$ & 29,4 & 28,5 \\
\hline $\mathrm{La}$ & 21,4 & 47,5 \\
\hline $\mathrm{Ce}$ & 44,8 & 97,3 \\
\hline $\mathrm{Pr}$ & 5,04 & 11,68 \\
\hline $\mathrm{Nd}$ & 19,3 & 42,0 \\
\hline $\mathrm{Sm}$ & 4,38 & 8,06 \\
\hline $\mathrm{Eu}$ & 0,40 & 1,17 \\
\hline $\mathrm{Gd}$ & 4,35 & 7,26 \\
\hline $\mathrm{Tb}$ & 0,78 & 1,07 \\
\hline $\mathrm{Dy}$ & 4,95 & 6,02 \\
\hline $\mathrm{Ho}$ & 1,00 & 1,16 \\
\hline $\mathrm{Er}$ & 3,15 & 3,21 \\
\hline $\mathrm{Tm}$ & 0,49 & 0,43 \\
\hline $\mathrm{Yb}$ & 3,20 & 2,79 \\
\hline $\mathrm{Lu}$ & 0,51 & 0,42 \\
\hline
\end{tabular}


Zmíněný autor popisuje, že ve vzorcích z hloubek $11,6 \mathrm{~m}$ a $12,9 \mathrm{~m}$ naprosto dominoval smektit (montmorillonit), zatímco ve vzorku $\mathrm{z}$ hloubky $18,5 \mathrm{~m}$ byly kromě smektitu (montmorillonitu) přítomny také další jílové minerály (illit a kaolinit) a primární minerály vulkanoklastik (křemen, plagioklas, biotit, muskovit a chlorit). Při vzniku smektitu (montmorillonitu) je důležitá vysoká aktivita $\mathrm{Si}(\mathrm{OH})_{4}, \mathrm{Mg}^{2+}, \mathrm{Ca}^{2+}$ a $\mathrm{pH}$ nad 6,5, naproti tomu při $\mathrm{pH}$ nižším než 6 vzniká vermikulit a následně kaolinit (Borchardt 1989; Christidis a Huff 2009). Vzhledem k zjištěnému stáří a geologické pozici vulkanoklastik (Čtyroký 1982, 1991; Čížek et al. 1990; Nehyba a Roetzel 1999) předpokládáme, že na lokalitě Ivančice-Réna proběhla sedimentace vulkanického popela v lakustrinním prostředí.

Vulkanoklastika na lokalitě Lipník nad Bečvou (LV022) jsou však situována uvnitř komplexu jílů badenského stáŕí. Jednalo se tedy o sedimentaci do marinního prostředí, což možnost interakce s fluidy produkovanými $\mathrm{v}$ průběhu kontinentálního zvětrávání vylučuje. Je tedy pravděpodobné, že k sekundárním přeměnám došlo $\mathrm{v}$ důsledku interakce vulkanického skla s mořskou/diagenetickou vodou. $\mathrm{V}$ př́padě vulkanoklastik na lokalitě Ivančice-Réna (BP402) mohlo k podobné alteraci dojít $\mathrm{v}$ průběhu pozdější diageneze zmíněných vulkanoklastik po transgresi badenského moře. Absence negativní Ce anomálie u obou vzorků naznačuje, že přeměna na sekundární minerály probíhala za suboxických nebo anoxických podmínek (Jeans et al. 2000).

Sekundární přeměny biotitových vyrostlic se především projevily ztrátou $\mathrm{K}_{2} \mathrm{O}$ a $\mathrm{FeO}+\mathrm{Fe}_{2} \mathrm{O}_{3}$. Železo a mangan se v hornině hromadí v podobě oxo-hydroxidů Mn-Fe. V mikroskopu (obr. 2) jsou patrné drobné shluky oxo-hydroxidů Mn-Fe (dále limonity), které z velké části vznikají rozpadem vulkanického skla a biotitu. Někdy je limonit ostře ohraničen a částečně obklopen vulkanickým sklem (obr. 3b) což naznačuje, že mohl vzniknout rozpadem železem bohatých minerálů (pyrit, magnetit).

\section{Závěr}

Tento př́spěvek je zaměřen na petrografickou a geochemickou charakteristiku dvou vzorků miocenních ryolitových vulkanoklastik z lokalit Lipník nad Bečvou a Ivančice-Réna. Na obou lokalitách byly nalezeny vrstvy vulkanického popela, který měl chemické složení odpovídající ryolitu. Obsahy REE a dalších stopových prvků ( $\mathrm{Y}=28$ a $29 \mathrm{ppm}, \mathrm{Yb}=2,8$ a 3,2 $\mathrm{ppm}, \mathrm{Nb}=12$ a 14 ppm, Ta $=1,1$ a 1,2 ppm, Zr/Ti 0,16 a 0,17 a Nb/Y $=0,4$ a 0,5$)$ podporují názor, že oba studované vzorky pochází z podobného magmatického zdroje. Vulkanoklastika z lokality Ivančice-Réna sedimentovala ve spodním miocénu v terestrických podmínkách (lakustrinní prostředí), naproti tomu vulkanoklastika z okolí Lipníka nad Bečvou jsou součástí sedimentárního sledu mořských sedimentů.

V obou studovaných vzorcích dominuje smektit, který zatlačuje ostrohranné stř́ípky vulkanického skla a klasty pemzy. V malém množství jsou přítomny úlomky krystalů živců, křemene, muskovitu a biotitu. Smektit a podružně zastoupený opál částečně nahrazují sopečné sklo a střepy pemzy. Krystaly plagioklasu $\left(\mathrm{Ab}_{59-60}\right)$ a K-živce $\left(\mathrm{Or}_{62-78} \mathrm{Ab}_{21-33} \mathrm{An}_{0-1}\right)$ jsou relativně čerstvé (slabá přeměna na sericit). Biotit je částečně až zcela oxidován a chloritizován $\left(4,9-6,2\right.$ hm. \% $\left.\mathrm{K}_{2} \mathrm{O}\right)$. V menším množství jsou přítomny oxyhydroxidy železa. Sekundární přeměny vulkanického skla jsou provázeny úbytkem $\mathrm{K}$ a $\mathrm{Na} v$ důsledku interakce s vodními roztoky. Smektit patrně vznikal in situ poté, co vulkanoklastika sedimentovala do lakustrinního nebo mořského prostředí.

\section{Poděkování}

Předložená práce vznikla za finanční podpory projektů České geologické služby číslo 321180 a 321070 (DKRVO/ ČGS 2018-2022). Autoři děkují recenzentưm Z. Dolníčkovi a D. V̌̌ianskému za podnětné pripomínky. 


\section{Literatura}

Borchardt, G. (1989). Smectites. - In: Dixon, J. B., Weed, S. B. (eds): Minerals in Soil Environments, 675-727. https://doi.org/10.2136/ sssabookser1.2ed.c14

Boynton, W. V. (1984). Cosmochemistry of the rare earth elements: meteoritic studies. - In: Henderson, P. (ed.): Rare Earth Elements Geochemistry. - 63-114, Amsterdam (Elsevier).

Bubík, M., Břízová, E., Buriánek, D., Gilíková, H., Havíř, J., Janderková, J., Kašperáková, D., Knésl, I., Kolejka, V., Konečný, F., Krejčí, O., Kryštofová, E., Otava, J., Pecina, V., Pořádek, P., Sedláček, J., Sedláčková, I., Švábenická, L., Skácelová, Z., Tomanová Petrová, P., Večeřa, J., Vít, J. (2018a). Vysvětlivky k základní geologické mapě ČR list Lipník nad Bečvou 25-132. - MS [archivní zpráva], Česká geologická služba. Praha.

Bubík, M., Gilíková, H., Otava, J., Tomanová Petrová, P., Vít, J. (2018b). Základní geologická mapa České republiky $1: 25$ 000, list 25-132 Lipník nad Bečvou. - Česká geologická služba. Praha.

Bubík, M., Gilíková, H., Otava, J., Tomanová Petrová, P., Švábenická, L., Vít, J. (2019). Nové poznatky o terciéru a kvartéru získané geologickým mapováním okolí Lipníka nad Bečvou. - Geologické výzkumy na Moravě a ve Slezsku, 26, 1-2, 7-15.

Čížek, P. (1980). Výskyt bentonitu jihovýchodně od Ivančic. - Geologický průzkum 22, 298-300. Praha.

Čížek, P. (1982). Zpráva o nálezu a stavu výzkumu ložiska bentonitu jv. od Ivančic. - ČGS Praha. P03897

Čížek, P., Koeppl, O., Krejčíŕ, M., Krmíček, P., Pekárková, R. (1990). Lower Miocene bentonites of the Carpathian Foredeep in southern Moravia. - Acta Musei Moraviae, Scientiae geologicae, 75, 105-114. Brno.

Čtyroký, P. (1982). Spodní miocén (eggenburg a ottnang) jz. části čelní hlubiny na Moravě (The Lower Miocene (Eggenburg-Ottnang) in the SW-part of the Carpathian Foredeep in Moravia). - Zemní plyn a nafta, 27, 379-394. Hodonín.

Čtyroký, P. (1991). Členění a korelace eggenburgu a ottnangu v jižní části karpatské předhlubně na jižní Moravě (Classification and correlation of the Eggenburgian and Ottnangian in the southern part of the Carpathian Foredeep in Southern Moravia). - Západné Karpaty, Séria Geológia, 15, 67-109, Bratislava.

Daux, V., Guy, C., Advocat, T., Crovisier, J. L., Stille, P. (1997). Kinetic aspects of basaltic glass dissolution at $90^{\circ} \mathrm{C}$ : role of aqueous silicon and aluminium. - Chemical Geology, 142, 109-126. https://doi.org/10.1016/S0009-2541(97)00079-X

Ddani, M., Meunier, A., Zahraoui, M., Beaufort, D., El Wartiti, M., Fontaine, D., Boukili, B., El Mahi, B. (2005). Clay mineralogy and chemical composition of bentonites from the Gourougou volcanic massif (northeast Morocco). - Clays and Clay Minerals, 53, 250-267. https://doi.org/10.1346/CCMN.2005.0530305

Fiore, S., Huertas, F. J., Tazaki, K., Huertas, F., Linares, J. (1999). A low temperature experimental alteration of a rhyolitic obsidian. - European Journal of Mineralogy, 11, 455-469. https://doi.org/10.1127/ejm/11/3/0455

Fisher, R. V., Schmincke, H-U. (1984). Alteration of Volcanic Glass. - In: Fisher, R. V., Schmincke, H-U. (eds): Pyroclastic Rocks. - Springer, Berlin, Heidelberg, pp. 312-345. https://doi.org/10.3390/min9110696

García-Romero, E., María Manchado, E., Suárez, M., García-Rivas, J. (2019). Spanish Bentonites: A Review and New Data on Their Geology, Mineralogy, and Crystal Chemistry. - Minerals, 9, 11, 696.

Güven, N. (1988). Smectites. - In: Bailey, S. W. (ed.). - Hydrous Phyllosilicates. Reviews in Mineralogy, Mineralogical Society of America, 19, 497-559.

Christidis, G. E., Huff, W. D. (2009). Geological Aspects and Genesis of Bentonites. - Elements, 5, 2, 93-98. https://doi.org/10.2113/ gselements.5.2.93

Iijima, A. (1978). Geological occurrences of zeolite in marine environments. - In: Sand, L. B., Mumpton, F. A. (eds): Natural Zeolites: Occurrence, Properties, Use. - Pergamon Press, Elmsford, New York, 175-198.

Izett, G. A., Wilcox, R. E., Powers, H. A., Desborough, G. A. (1970). The Bishop ash bed, a Pleistocene marker bed in the Western United States. - Quaternary Research, 1, 1, 121-132. https://doi.org/10.1016/0033-5894(70)90014-1

Jeans, C. V., Wray, D. S., Merriman, R. J., Fisher, M. J. (2000). Volcanogenic clays in Jurassic and Cretaceous strata of England and the North Sea Basin. Clay Minerals, 35, 25-55.

Jurková, A., Tomšík, J. (1959). Tufitické horniny v tortonu ostravsko-karvinského revíru. - Časopis pro mineralogii a geologii, $4,4,394-407$.

Kadir, S., Külah, T., Erkoyun, H., Christidis, G. E., Arslanyan, R. (2019). Geology, Mineralogy, Geochemistry, and Genesis of Bentonite Deposits in Miocene Volcano-Sedimentary Units of the Balikesir Region, Western Anatolia, Turkey. - Clays and Clay Minerals, 67, 371-398. https://doi.org/10.1007/s42860-019-00029-w

Kohut, M., Anczkiewicz, R., Biron, A., Mikus, T., Milovska, S., Milovsk, R., Surka, J., Danisik, M., Kirkland, Ch., Erban, V., Kochergina, Yu., Magna, T., Gerdes, A., Halton, A., Sherlock, S., Jesenak, K., Pearce, N., Recio, C., Westgate, J., Baco, P. (2019). Genesis of the Carpathian obsidians. In Broska, I.Kohut, M., Kohut, M., Tomasovych, A. (eds). Geologica Carpathica 70 Proceedings of the Geologica Carpathica 70 Conference, 75-78.

Kolek, P., Krmíček, P., Palan, M. (1990). Vysoce čisté bentonity. Účel: bentonit pro speciální účely. Etapa: aplikovaný výzkum. ČGS Praha. P69900.

Krmíček, P., Čížek, P. (1992). Výpočet a klasifikace zásob ložiska Ivančice-Réna, bentonit, č. ú. 23584692. - Bentonit Moravia, s.r.o. Ivančice. ČGS Praha. P075976.

Kronberg, B. I., Nesbitt, H. W. (1981). Quantification of weathering, soil geochemistry and soil fertility. - Journal of Soil Science, 32, 453-459. https://doi.org/10.1111/j.1365-2389.1981.tb01721.x

Krystek, I. (1959). Petrografie tufitických hornin z oblasti vídeňské vnitrokarpatské a vněkarpatské pánve. - Geologické práce, 54, 127-144.

Krystek, I. (1981). Použití výzkumu společenstev těžkých minerálů v sedimentárních komplexech. - Folia Facultatis Scientiarum Naturalium Universitatis Purkynianae Brunensis, Geologia, 22, 3, 101-107.

Le Bas, M. J., Le Maitre, R. W., Streckeisen, A., Zanettin, B. (1986). A chemical classification of volcanic rocks based on the total alkali-silica diagram. - Journal of Petrology, 27, 745-750. https://doi.org/10.1093/petrology/27.3.745 
Macoun, J., Cicha, I., Čekan, V., Jurková, A., Otava, J., Strakošová, O., Vítek, J. (1985). Vysvětlivky k základní geologické mapě ČSSR $1: 25000$ 15-432 Ostrava. - ČGS Praha. P052062.

Márton, E., Tokarski, A., Krejčí, O., Rauch, M., Olszewska, B., Tomanová Petrová, P., Wójcik, A. (2011). ,Non European paleomagnetic directions from the Carpathian Foredeep at the southern margin of the European plate. - Terra Nova, 23, 2, 134-144. https://doi.org/10.1111/j.1365-3121.00993.x

McDonough, W. F., Sun, S.-S. (1995). Composition of the Earth. - Chemical Geology, 120, 223-253. https://doi.org/10.1016/00092541(94)00140-4

Melka, K., Štastný, M. (2014). Encyklopedický přehled jílových a příbuzných minerálů. Academia Praha. 914 s. ISBN 978-80200-2369-8.

Merlet, C. (1994). An accurate Computer Correction Program for Quantitative Electron Probe Micro-analyses. - Microchimica Acta, 114, 115, 363-376. https://doi.org/10.1007/BF01244563

Nehyba, S. (1997). Miocene volcaniclastics of the Carpathian Foredeep in the Czech Republic. - Věstník Českého geologického ústavu, 72, 4, 311-327.

Nehyba, S., Roetzel, R. (1999). Lower Miocene Volcaniclastics in South Moravia and Lower Austria. - Jahrbuch der Geologischen Bundesanstalt, 141, 473-490.

Nehyba, S., Stráník, Z. (2016). Vulkanoklastika v pavlovickém souvrství ždánické jednotky. - Geologické výzkumy na Moravě a ve Slezsku, 12, 37-41.

Nesbitt, H. W., Young, G. M. (1982). Early Proterozoic climates and plate motion inferred from major element chemistry of lutites. - Nature, 299, 715-717. https://doi.org/10.1038/299715a0

Nesbitt, H. W., Young, G. M., McLennan S. M., Keays R. R. (1996). Effects of Chemical Weathering and Sorting on the Petrogenesis of Siliciclastic Sediments, with Implications for Provenance Studies. - The Journal of Geology, 104, 5, 525-542. https://doi.org/10.1086/629850

Pálenský, P., Nekovařík, Č, Růžička, M. (1997). Geologická mapa 1 : 50 000, list 24-34 Ivančice. - Český geologický ústav Praha.

Pavlík, J. (1987). Technologické hodnocení bentonitů a doprovodných surovin lokality Ivančice-Réna. - Sborník Geologického průzkumu Ostrava, 32, 145-151.

Pearce, J. A., Harris, N. W., Tindle, A. G. (1984). Trace element discrimination diagrams for the tectonic interpretation of granitic rocks. - Journal of Petrology, 25, 956-983. https://doi.org/10.1093/petrology/25.4.956

Pécskay, Z., Lexa, J., Szakács, A., Seghedi, I., Balogh, K., Konečný, V., Zelenka, T., Kovacs, M., Póka, T., Fülöp, A., Márton, E., Panaiotu, C., Cvetković, V. (2006). Geochronology of Neogene magmatism in the Carpathian arc and intra-Carpathian area. - Geologica Carpathica, 57, 6, 511-530.

Peloušek, J., Sirný, J. (1997). Přerov - Hranice, cihlářské suroviny, vyhledávací průzkum (I. etapa). - ČGS Praha. P97493.

Peloušek, J., Sirný, J. (1998). Přerov - Hranice, cihlářské suroviny, vyhledávací průzkum (II. etapa). - ČGS Praha. P97494.

Preece, S., Westgate, J. A., Gorton, M. P. (1992). Compositional variation and provenance of Late Cenozoic distal tephra beds, Fairbanks area, Alaska. - Quaternary International, 192, 97-101. https://doi.org/10.1016/1040-6182(92)90015-T

Roetzel, R., de Leeuw, A., Mandic, O., Márton, E., Nehyba, S., Kuiper, K. F., Scholger, R., Wimmer-Frey, I. (2014). Lower Miocene (upper Burdigalian, Karpatian) volcanic ash-fall at the south-eastern margin of the Bohemian Massif in Austria - New evidence from 40Ar/39Ar-dating, palaeomagnetic, geochemical and mineralogical investigations. - Austrian Journal of Earth Sciences, 107, 2-22.

Roetzel, R., Scharbert, S., Wimmer-Frey, I. Decker, K., (1999). B3 Straning - Bahneinschnitt. - In: Roetzel, R. (ed.): Arbeitstagung der Geologischen Bundesanstalt 1999 - Retz-Hollabrunn. 290-293, Wien (Geologische Bundesanstalt).

Shiraki, R., Sakai, H., Endoh, M., Kishima, N. (1987). Experimental studies on rhyolite- and andesite-seawater interactions at $300{ }^{\circ} \mathrm{C}$ and 1000 bars. - Geochemical Journal, 21, 139-148. https://doi.org/10.2343/geochemj.21.139

Schandl, S. J., Gorton, M. P. (2002). Application of high field strength elements to discriminate tectonic settings in VMS environments. - Economic Geology, 97, 629-642. https://doi.org/10.2113/gsecongeo.97.3.629

Schulze, D. G. (2005). Clay minerals. - Encyclopedia of Soils in the Environment, 246-254. https://doi.org/10.1016/b0-12-3485304/00189-2

Slavík, J. (1956). Zpráva o dacitových tufitech v mořském tortonu vněkarpatské pánve na Moravě. - Věstník Ústředního ústavu geologického, 31, 1, 29-36.

Taylor, S. R., McLennan, S. M. (1995). The geochemical evolution of the continental crust. - Review Geophysics, 33, $241-265$. https://doi.org/10.1029/95RG00262

Internetové zdroje:

www.geology.cz/stratigraphy/

www.geology.cz/mapove aplikace/

SurIS (https://mapy.geology.cz/suris/)

Vrtná prozkoumanost (https://mapy.geology.cz/vrtna_prozkoumanost/)

ASGI (http://www.geology.cz/app/asgi/) 